\title{
A REPRESENTAÇÃO DA MULHER CRIMINOSA NA REVISTA VEJA
}

\author{
THE REPRESENTATION OF THE CRIMINAL WOMAN IN THE VEJA MAGAZINE
}

Eduarda Toscani Gindri

\begin{abstract}
Mestranda no Programa de Pós-Graduação em Direito da Universidade de Brasília. Graduada em Direito pelo Centro Universitário Franciscano (2014), e bacharel em Comunicação Social - Jornalismo pela Universidade Federal de Santa Maria (2013). Advogada. E-mail: etoscanigindri@gmail.com
\end{abstract}

Recebido em: 16/10/2016

Aprovado em: 28/11/2016

Doi: $10.5585 / \mathrm{rdb} . v 15 i 6.508$

RESUMO: A pesquisa teve o objetivo de investigar a representação da mulher criminosa no discurso do jornalismo da revista Veja. Inicialmente, explorou as discussões teóricas sobre crime e mulher pelos marcos do paradigma de gênero e da criminologia crítica. $O$ jornalismo foi entendido como um espaço de construção de sentidos em forma de narrativas. Com estes fundamentos, foi realizada uma Análise de Discurso a partir do texto de quatro edições da revista Veja, entre 2003 e 2013, que traziam mulheres criminosas em reportagens de capa. A análise considerou a pesquisa realizada por Yvonne Jewkes (2004), que identificou oito formas narrativas padrão que o jornalismo lança mão ao falar da criminalidade feminina: 1) sexualidade e desvio sexual; 2) atração física; 3) condição matrimonial, como más esposas; 4) maternidade, como más mães; 5) monstros mitológicos; 6) "vacas loucas"; 7) manipuladoras do mal; e 8) não agentes. Concluiu-se que as oito formas narrativas aparecem no jornalismo da revista Veja, mobilizados nas narrativas sobre mulheres criminosas, reforçando valores que contribuem para a construção de uma imagem estereotipada, reducionista, de acordo com padrões patriarcais de gênero que inferiorizam as mulheres.

Palavras-chave: Jornalismo; Criminologia Crítica; Análise do Discurso; Criminalidade feminina; Revista Veja

ABSTRACT: The research aimed to investigate the representation of criminal woman in
journalism speech of Veja magazine. Initially, it explored the theoretical discussions about crime
and woman upon the marks of gender paradigm and critical criminology. The journalism was
perceived as a space of construction of meaning in the form of narratives. With these
foundations, a Discourse Analysis was performed from the text of four issues of the magazine
Veja, between 2003 and 2013 , which brought criminal women in cover stories. The analysis
considered the research conducted by Yvonne Jewkes (2004), which identified eight standard
narrative forms that journalism uses when speaking of female crime: 1) sexuality and sexual
deviance; 2) physical attractiveness; 3) bad wives; 4) bad mothers; 5) mythical monsters; 6) "mad
cows; 7) evil manipulators; e 8) non-agents. The research concluded that the eight narrative
forms appear in Veja magazine, mobilized in narratives of criminal women, reinforcing values 
that contribute to the construction of a stereotypical and reductionist image, according to patriarchal gender patterns that undervalue women.

Keywords: Journalism; Critical Criminology; Discourse Analysis; Female Crime; Veja magazine

SUMÁRIO: Introdução; 1. Mulher e crime: nomeações entre determinismos e rupturas; 2. A narrativa jornalística e as representações sobre crime; 3. Percursos metodológicos; 4. Discursos sobre mulher e crime no jornalismo da Veja; Considerações finais; Referências.

\section{INTRODUÇÃO}

O jornalismo atua enquanto agente narrativo, como uma das formas contemporâneas da prática universal de contar histórias e, através delas, estruturar, organizar e compreender um mundo desconhecido e inacessível. Quando fala de alguém, o jornalismo percebe, desconstrói e reconstrói este outro, que dentro da notícia será um personagem com certo referente no mundo "real", uma representação deste alguém expressa em fragmentos de uma realidade muito mais ampla e inapreensível em sua completude. Esse processo pode levar à produção de distorções, pois constrói visões seletivas nas quais são atribuídos valores e características com significados atravessados por relações de poder.

Nas notícias sobre a criminalidade, os sujeitos que aparecem são tradicionalmente estigmatizados como desviantes e perniciosos à sociedade, incidindo uma seletividade baseada em critérios de raça, gênero e classe social. O tema desse trabalho é a representação do crime e da mulher nos meios de comunicação, e é atravessado por essas discussões. Diante disso, tem o objetivo de responder à questão: como são representadas as mulheres criminosas nas reportagens da revista Veja?

Para tanto, será apresentada uma breve revisão teórica que instrui o trabalho empírico. Inicialmente, algumas das possíveis abordagens sobre mulher e crime são apresentadas, seguindo o marco dos estudos de gênero e da criminologia crítica. $\mathrm{O}$ segundo momento é dedicado à discussão sobre o jornalismo e suas construção sobre o crime, pensando-o enquanto narrativa que se assemelha às narrativas mitológicas e populares, ao formar representações seletivas da realidade.

O terceiro tópico desse trabalho é a exploração do objeto de pesquisa, a revista Veja, através da abordagem teórica e metodológica da Análise de Discurso. O corpus de pesquisa selecionado consiste nas matérias de capa da Veja entre 2003 e 2013 que traziam mulheres que haviam cometidos crimes. As categorias de análise utilizadas são as desenvolvidos por Yvonne Jewkes (2004), no capítulo dedicado à criminalidade feminina da sua obra "Media And Crime", que resumem discursos usuais evocados sobre o tema.

\section{MULHER E CRIME: NOMEAÇÕES ENTRE DETERMINISMOS E RUPTURAS}

As conceituações construídas em torno das categorias "mulher" e "crime" já estiveram vinculadas à discursos deterministas, o que serviu como estratégia de legitimação para relações sociais desiguais. No caso das diferenças entre os corpos de homens e mulheres, hierarquias sociais foram legitimadas por um conjunto de preceitos biológicos, médicos, psiquiátricos, religiosos (entre outros). Por exemplo, o corpo e a saúde da mulher foram, até o século XX, campos obscuros de saber, mistérios que a medicina, quase integralmente masculina, tentava desvendar a partir dos lentos avanços científicos da época e sob a vigilância de dogmas católicos 
que barravam determinados métodos de aprendizagem e orientavam um discurso sobre o corpo feminino como recipiente de controvérsias, um lugar de embate entre Deus e o Diabo (DEL PRIORE, 1997).

Já a saúde mental da mulher estava relacionada à sua natureza, em especial, a sexual, enquanto a do homem, aos seus atributos sociais de trabalhador e provedor (ENGEL, 1997). Algumas verdades científicas do século XIX, embasadas no desenvolvimento da psicanálise, afirmavam que o corpo feminino estava propenso à doença mental: "a menstruação, a gravidez e o parto seriam, portanto, os aspectos essencialmente priorizados na definição e no diagnóstico das moléstias mentais que afetam mais frequentemente ou de modo específico as mulheres" (ENGEL, 1997, p. 333). Por esses contornos científicos, reiterava-se a crença na ambiguidade do corpo feminino, tão imprevisível que "a mulher transformava-se num ser moral e socialmente perigoso, devendo ser submetida a um conjunto de medidas normatizadoras extremamente rígidas que assegurassem o cumprimento de seu papel social de esposa e mãe" (ENGEL, 1997, p. 332).

O conceito de mulher saudável girava em torno de desvios sexuais, aqueles que "se circunscrevem, predominantemente, ao âmbito da ausência de relações sexuais ou à prática de relações sexuais sem a finalidade reprodutora" (ENGEL, 1997, p. 347). Exercer a sexualidade livre poderia culminar no diagnóstico mais comum de histeria, doença que acometeria majoritariamente (ou quase exclusivamente) mulheres dado seu corpo frágil, a função da maternidade ou como enfermidade de um útero que não é fecundado (ENGEL, 1997).

Foi buscando fugir desses determinismos presentes em diversos discursos que pesquisadoras feministas estadunidenses, na década de 1970, incorporaram o termo gênero aos seus estudos a fim de rejeitar as explicações biológicas:

[...] como aquelas que encontram um denominador comum para várias formas de subordinação no fato de que as mulheres têm filhos e que os homens têm uma força muscular superior. O gênero se torna, aliás, uma maneira de indicar as "construções sociais": a criação inteiramente social das ideias sobre os papéis próprios aos homens e às mulheres (SCOTT, 1995 p. 75).

Na perspectiva de gênero procura-se uma abordagem relacional, articulada com outros fatores de compreensão do indivíduo, como raça, sexualidade, classe social, religião, que ajudem a perceber como ele é visto e se vê num determinado tempo e espaço. Gênero funciona como uma categoria de análise que permite ampliar, contextualizar e problematizar as definições de masculinidade e feminilidade. Refletir sobre ela significa "assumir que é no interior da cultura e de uma cultura específica que características materiais adquirem significados" (LOURO, 2008, $p$. 22). Fazer-se mulher, assim como fazer-se homem, requer investimentos contínuos, processos minuciosos e sutis. É na cultura que aprendemos a viver o gênero, "através dos discursos repetidos da mídia, da igreja, da ciência e das leis e também, contemporaneamente, através dos discursos dos movimentos sociais e dos múltiplos dispositivos tecnológicos" (LOURO, 2008, p. 22).

A noção de crime, sistematizada em torno da criminologia e suas diferentes matizes, também passou por um processo de construção de discursos deterministas e um consequente esforço de ruptura. Mendes (2014) afirma que o Malleus Maleficarum, manual dos inquisidores da Idade Média usado para identificar, processar e punir bruxas, foi a primeira sistematização do discurso criminológico, integrando ainda normas de direito e processo penal. É a partir desse período que "se constrói o mais perfeito e coordenado discurso, não somente de exclusão ou limitação da participação feminina na esfera pública, mas de sua perseguição e encarceramento como pertencente a um grupo perigoso" (MENDES, 2014, p. 28).

Diante disso, ela conclui que "a criminologia nasceu como um discurso de homens, para homens, sobre as mulheres. E ao longo dos tempos, se transformou em um discurso de homens, para homens e sobre homens" (MENDES, 2014, p. 157). Esse período medieval marca o 
fortalecimento de um projeto de custódia das mulheres, atravessado por discursos jurídicos, médicos e teleológicos, como os anteriormente citados. Assim, é muito antes do capitalismo industrial (FOUCAULT, 1999; RUSCHE; KIRCHHEIMER, 1984) que o cárcere aparece como uma realidade para as mulheres: "o cárcere não foi uma novidade moderna para as que eram pobres e ociosas [...]. Tratava-se da custódia necessária às mulheres que não dispunham de 'proteção' masculina” (MENDES, 2014, p. 142).

No século XIX, sob a vigência de ideias do darwinismo social e do positivismo, se desenvolve a criminologia moderna com a escola positiva, cujo marco inicial é a publicação do Tratado Antropológico Experimental do Homem Delinquente, em 1876, obra de Cesare Lombroso. Para esses e outros estudiosos, "o criminoso será estudado como um doente, um escravo de sua herança patológica (determinismo biológico), como um ser impelido por processos causais que está incapacitado para compreender o social (determinismo social)" (MENDES, 2014, p. 38).

Lombroso e Ferrero, na obra “The Female Offender"(A mulher infratora) (1903), avaliaram a biologia feminina elencando que os traços das criminosas variavam do tamanho do crânio, da jugular, ao tamanho do clitóris, lábios vaginais, ou ainda características comportamentais como lesbianismo e masturbação. Os autores ainda qualificavam um grupo de mulheres como nascidas criminosas: dotadas de uma crueldade diabólica; carência de religiosidade; inteligência muito superior ou inferior; traços de virilidade; cometiam o crime por amor, vingança, ganância e avareza; motivações fúteis como assessórios de moda, etc.(LOMBROSO; FERRERO, 1903).

No Brasil, a apropriação das teorias criminológicas positivistas acompanhou também a apropriação de teorias sobre raça, o que, em uma sociedade pós-abolição, serviu de fundamento retórico para que se qualificasse o povo negro como como inferior e perigoso:

A recepção da criminologia na América Latina e sua modulação estratégica conectada às necessidades de ordenamento social está imersa nos pressupostos do racismo que inunda os circuitos acadêmicos do século XIX. Os reclamos por "ordem", bradados em voz alta pelas elites regionais nesse período, era a explicitação da antiga necessidade de controle da massa negra e indígena, então vestindo uma nova roupagem. O racismo é, portanto, a categoria que fundamenta o discurso de regulação social forjado pelos grupos hegemônicos latino-americanos para administração dos demais segmentos (FLAUZINA, 2008, p. 41).

Para as mulheres, a escola positiva representou mais uma nova ciência que "teve o papel de comprovar a suposta inferioridade feminina, além de delimitar os comportamentos aceitos dentro da chamada 'normalidade', ou seja, comportamentos que não fossem contrários às normas sociais e aos papeis esperados para as mulheres" (FARIA, 2010, p. 6070). No contexto brasileiro, portanto, as construções modernas sobre mulheres e homens perigosos estão atravessadas por uma herança racista e colonial que hoje faz eco nos dados prisionais.

Segundo o Relatório de 2014 do Departamento Penitenciário Nacional, a população prisional brasileira era de 607.731 pessoas, das quais, 37.380 são mulheres, 542.407 são homens, $41 \%$ são presos sem condenação, a maioria são jovens entre 18 e 29 anos (56\%), com até o ensino fundamental completo (53\%) e autodeclarada negra $(67 \%)$ Além disso, a maioria dessas pessoas em privação de liberdade responde por crimes de tráfico de entorpecentes $(27 \%)$, roubo (21\%), homicídio (14\%) e furto (11\%). (BRASIL, 2014a). Esse quadro adquire outros contornos quando é feito um recorte de gênero. Nas porcentagens de homens, $25 \%$ respondem por tráfico e $21 \%$ por roubo. Já no caso das mulheres, mais da metade, $63 \%$, estão presas em razão de crimes de tráfico de entorpecentes e $7 \%$ para casos de roubo, $8 \%$ para casos de furto. Além disso, embora os números de homens presos sejam maiores, a taxa de crescimento da população 
prisional feminina assusta: enquanto a masculina subiu 91,02\% entre 2005 e 2014, no mesmo período, a de mulheres cresceu 189,20\% (BRASIL, 2014b).

As teorias das escolas positivas tanto não explicavam as relações de poder inerentes aos processos de criminalização, quanto às negligenciavam e legitimavam a ordem social desigual que criminalizava majoritariamente homens negros e de classes baixas. Buscando evidenciar essa realidade omitida, na década de 1970 , com base nas teorias sociológicas do conflito ${ }^{1}$, na abordagem das teorias da reação social ${ }^{2}$ e com um enfoque marxista da questão criminal, se desenvolve a criminologia crítica.

$\mathrm{Na}$ visão criminológico-crítica, a criminalidade se constitui como um ato valorativo, um "status atribuído a determinados indivíduos por parte daqueles que detêm o poder de criar e de aplicar a lei penal, mediante mecanismos seletivos, sobre cuja estrutura e funcionamento, a estratificação e o antagonismo dos grupos sociais tem uma influência fundamental" (BARATTA, 2002, p. 113). Esse processo de distribuição do status de criminoso ocorre no sistema capitalista, e assim, é um "bem negativo', distribuído desigualmente conforme a hierarquia dos interesses fixada no sistema socioeconômico e conforme a desigualdade social dos indivíduos" (BARATTA, 2002, p. 161) ${ }^{3}$.

A criminologia crítica conclui que o sistema penal concorre para a manutenção das desigualdades sociais enquanto criminaliza majoritariamente pobres e suas condutas típicas, como violações à propriedade, e imuniza as classes altas, detentoras do poder de criar leis, criminalizando em menor grau aquelas que eles cometem (BARATTA, 2002). A principal ruptura da criminologia crítica é, portanto, a de redirecionar o foco desse campo de estudo do criminoso, da criminosa e das causas do crime, para os processos de criminalização, imunização e vitimização, ou seja, para o sistema penal e suas ações de rotulação (ANDRADE, 2012; BARATTA, 2002).

Porém, embora os processos de criminalização e vitimização sejam atravessados - na sua incidência ou na sua negligência - por marcadores de raça e de gênero, a criminologia crítica ainda não incorporou profundamente a análise dessas estruturas. Parte dessas críticas são feitas pelo campo que se denominou "criminologia feminista" - um vasto conjunto de abordagens que oferecem uma intersecção entre criminalidade, gênero, e outras estruturas da sociedade (JEWKES, 2004).

Embora autoras como Andrade (2012) postulem que a criminologia crítica tem incorporado o marco de gênero, outras (ALIMENA, 2010; MENDES, 2014) apontam que uma abordagem preocupada com a vida das mulheres, que incorpore uma epistemologia feminista, ainda é insipiente e marginal no campo da criminologia crítica. É fato que esforços nesse sentido vem crescendo no Brasil, ainda mais em face da preocupação com o aumento exponencial do encarceramento feminino e das exigências feministas de atenção às violências contra as mulheres

\footnotetext{
1 As teorias do conflito argumentam que: “a) interesses que estão na base da formação e da aplicação do direito penal são os interesses daqueles grupos que tem o poder de influir sobre os processos de criminalização - os interesses protegidos através do direito penal não são, pois, interesses comuns a todos os cidadãos; b) a criminalidade, no seu conjunto, é uma realidade social criada através do processo de criminalização" (BARATTA, 2002, p.119).

2 O Labeling Approach, também chamado de teorias da reação social e teoria do etiquetamento, não considera a realidade como pré-construída, mas construída dentro da prática da sociedade, dos processos de interação, tipificação e definição social. Assim, o desvio é um status atribuído pela sociedade a um indivíduo ou comportamento considerados desviantes. São autores de destaque para essa corrente teórica: Edwin Lemert, Howard Becker, Erving Goffman e David Matza (BARATTA, 2002).

3 Para Andrade, o sistema constrói e co-constitui o universo da criminalidade: “[...] mediante: a) a definição legal de crimes pelo Legislativo, que atribui à conduta o caráter criminal, definindo-a (e, com ela, o bem jurídico a ser protegido) e apenando-a qualitativa e quantitativamente (criminalização primária); b) a seleção das pessoas que serão etiquetadas, num continuum pela Polícia-Ministério Público e Justiça (criminalização secundária); e c) estigmatizadas, especialmente na prisão, como criminosos, entre todos aqueles que praticam tais condutas (criminalização terciária)" (ANDRADE, 2005, p. 80).
}

Revista de Direito Brasileira | São Paulo, SP | v. 15 | n. 6 | p. 270 - 294 | set./dez. 2016 
também no âmbito penal. Guardadas essas controvérsias, abordar a criminologia com um olhar feminista traz a possibilidade de perceber o fenômeno da criminalidade sob a lente de gênero e analisar como as construções sobre masculinidade e feminilidade influenciam nos processos de criminalização e vitimização. Para Mendes:

O paradigma feminista implica uma radicalização completa na medida em que perspectiva de gênero não é um "aditivo", como ocorre em análises criminológicas realizadas sob o paradigma da reação social. Ademais, o reconhecimento do processo de custódia, construído ao longo dos séculos, e vigente até nossos dias, torna impossível a adoção do sistema de justiça criminal como objeto principal (no mais das vezes único) do campo de conhecimento (MENDES, 2014, p. 158).

Assim, incorporar as análises de gênero, inseridas no marco interseccional (CRENSHAW, 2002), é um verdadeiro giro epistemológico no campo da criminologia, que desde a década de 1970 tem produzido avanços, mesmo que bastante centrados às perspectivas exploratórias de classe social. Esse giro implica considerar que as "mulheres sempre foram vítimas de penas públicas e privadas, de castigos, de critérios de condenação jurídicos e extrajurídicos, fundados no papel de gênero que deveriam representar" (MENDES, 2014, p. 153154). Nessa linha, representações sociais negativas produzidas pelos meios de comunicação, enquanto agências do controle penal, não são apenas reproduções do simbolismo patriarcal, mas também formas de punição públicas através da imagem dessas mulheres. Explorando melhor esse tema, o próximo tópico aborda a noção de jornalismo como narrativa e a apropriação dessa perspectiva para pensar as reportagens e notícias sobre crime.

\section{A NARRATIVA JORNALÍSTICA E AS REPRESENTAÇÕES SOBRE CRIME}

O jornalismo, para Motta, é uma forma de narrativa de realidade, pois, narrar é dispor estrategicamente de fatos com objetivo de produzir efeitos, com vontade de sentido de veridicção, através de uma linguagem "referencializada, objetivada, com farto uso de citações, números, estatísticas, referências espaço-temporais, artigos definidos, etc., produzindo então uma coerência referencializada" (MOTTA, 2013, p. 39).

As teorias mais recentes avaliam que os meios de comunicação não tem poder de influenciar diretamente as ações do público, como acreditava-se na primeira metade do século XX. Seus efeitos são indiretos e mediatos, com o poder de pautar determinados temas, segundo enquadramentos específicos, e fazer com esses se tornem agendas da discussão pública (WOLF, 2003). Nesse sentido afirma Budó (2006, p. 8):

[...] mais do que divulgar acontecimentos, o jornalismo possui um papel de definir quais são os fatos que repercutirão na mídia, e quais não serão conhecidos. Além desse quadro de abordagem da realidade, ainda o jornalista define qual o ângulo será privilegiado na notícia, mesmo que isto ocorra inconscientemente. Quando se trata de notícias sobre crimes, o senso comum jornalístico é preponderante ao definir a forma de abordagem do fato.

A notícia, principal produto do jornalismo, é fruto de "uma percepção consciente ou inconscientemente seletiva da realidade por parte do jornalista a partir de seus critérios profissionais, pessoais ou institucionais" (MOTTA, 2002a, p. 04). Pensar a notícia enquanto narrativa é perceber que ela é um tipo específico de sistema simbólico que possui uma dimensão das estórias, que transcende o informar e faz parte de uma prática cultural antiga e ritualística. As 
notícias são, para Bird e Dardene, narrativas mitológicas, pois "como os mitos, não contam as coisas como elas são, mas contam as coisas segundo o seu significado" (1993, p. 267). Os leitores consomem um texto com definições simbólicas que remetem aos traços culturais que estão associados aos mais diversos mitos que formam o seu imaginário. Os autores afirmam que muito dessa característica mítica das notícias “deriva de uma tal 'ressonância' - a sensação de termos escrito ou lido as mesmas 'estórias' repetidas vezes” (BIRD \& DARDENE, 1993, p. 268).

Esta característica lembra um dos 12 valores-notícia ${ }^{4}$ delimitados por Galtung e Ruge (1965 5 apud TRAQUINA, 2005, p. 69-70): "a consonância, isto é, a facilidade de inserir o 'novo' numa 'velha' ideia que corresponda ao que se espera que aconteça". Tal qual outros valores de noticiabilidade, a consonância também faz parte dos mesmos valores dos quais um contador de contos faz uso: "referem-se ao diferente e ao particular que representam, no entanto, algo universal" (BIRD \& DARDENE, 1993, p. 269). Além disso, para os autores: "através do mito e do folclore, os membros de uma cultura aprendem valores, definições do bem e do mal, e algumas vezes podem sentir emoções substitutivas - nem todas através de contos individuais, mas através de um conjunto de tradições e crenças populares" (BIRD \& DARDENE, 1993, p. 266). O relacionamento da notícia com o mito também está presente no pensamento de Motta: "as notícias objetivas revelam pré-configurações simbólicas, categorias mitológico-literárias que as conformam, como se os jornalistas estivessem sempre à espera de acontecimentos que preencham seus moldes ontológicos ou epistemológicos" (2002a, p. 11).

Motta aponta que a notícia "desencadeia um processo de negociação de sentidos ao longo da duração do acontecimento, que precisa ser nomeado, confrontado, avaliado e assimilado" (MOTTA, 2002a, p. 04). Este processo de dominar o incompreendido e o extraordinário é o que Motta chama de trabalho simbólico da notícia. Ela introduz um acontecimento novo ao fluxo de fatos esperados, o que gera conflito de sentidos, ambiguidades e desordem simbólica: a notícia "introduz o incomum no universo do comum, introduz o diferente no mundo da estabilidade" (MOTTA, 2002a, p. 5). O trabalho simbólico da notícia, é então o trabalho incessante da restauração da ordem, de familiarização deste desconhecido: "para cada obra do acaso, a necessidade de mensuração, de nomeação e confrontação do ambíguo ameaçador com o ordinário compreendido, e de conformação de sua significações para o controle deste significado fugido" (MOTTA, 2002a, p. 08).

Se o papel da notícia é fazer frente aos conflitos simbólicos originados dos relatos de acontecimentos inéditos e desestruturadores, também é possível encontrar na representação da notícia uma forma de familiarizar o estranho:

As notícias veiculadas pelos meios de comunicação são o lugar de convergência dos discursos jornalísticos que informam sobre a desordem, mas também o lugar de convergência e divergência dos diversos discursos que reelaboram, contrastam e confrontam as ocorrências e as suas significações. Neste processo, o jornalismo convoca, estabelece competências, cria e legitima atores, 
dimensiona e constrói os acontecimentos, mas vai também gerar cognitivamente novos consensos, reintroduzindo a ordem onde havia desordem, tornando familiar o que antes era não familiar, construindo novas atualidades e realidades (MOTTA, 2002a, p. 07)

Portanto, a narrativa "une pontos, ordena antecedentes e consequentes, relaciona coisas, cria o passado, o presente e o futuro, encaixa significados parciais em sucessões temporais, explicações e significações estáveis" (MOTTA, 2013, p. 71). Para o autor, “o ideológico e o simbólico se tocam e interagem no imaginário, interpenetrando-se e influindo-se mutuamente, tornando às vezes difícil não só identificar ideologias de classe puras como ideologias sem contradições políticas ou estéticas" (MOTTA, 2002b, p. 105).

A prática jornalística, por sua vez, se dá em normas próprias desse campo da produção cultural. Para Veiga da Silva, os padrões de gênero atravessam a prática social do jornalismo. , Ao analisar o processo de produção da notícia e distribuição dos encargos profissionais, concluiu que as notícias de hierarquia superior são aquelas relacionadas aos atributos masculinos: as investigativas, de risco, de assuntos 'sérios', "e para esse tipo de notícia, os jornalistas propostos eram preferencialmente do sexo masculino e com determinadas características de gênero consolidadas e reconhecidas por seus pares" (VEIGA DA SILVA, 2010, p. 158). Nas tomadas de decisão, "as posições de sujeito, visões de mundo e valores culturais dos jornalistas são acionados inconscientemente na atuação profissional” (VEIGA DA SILVA, 2010, p. 200).

Quando fala da mulher, o jornalismo retoma construções simbólicas cristalizadas no imaginário popular, as quais estão convencionadas como construções ideológicas de gênero e, dessa forma, acaba reproduzindo a cultura e reiterando visões de mundo. Para a ativista e pesquisadora feminista Rachel Moreno, a mulher que a mídia retrata:

[...] tem de ser casada ou aspirar ao casamento, ter filhos ou aspirar à maternidade, ser ou parecer jovem, ser vaidosa, cuidadosa. Ser branca, heterossexual, monogâmica, fiel, comportada, decidir mais com a emoção do que com a razão, ser sensível e delicada preocupar-se mais em cuidar dos outros do que com qualquer outra questão, mesmo que trabalhe e tenha grandes responsabilidades profissionais ou políticas (MORENO, 2008, p. 45).

Já o crime mobiliza grande parte da atenção do jornalismo, pois, reúne uma grande quantidade de valores-notícia, aplicando a estrutura: "um crime mais violento, com um maior número de vítimas equivale a maior noticiabilidade para esse crime. Qualquer crime pode ficar com mais valor se a violência lhe estiver associada" (TRAQUINA, 2005, p. 85). Além disso, a suposta atribuição de uma função de policiamento ao jornalismo perpassa a ideia de que ele deve denunciar os desvios que ocorrem na sociedade (TRAQUINA, 2005). Para Traquina (2005), a notícia sobre crime é geralmente rotineira e breve, pois a criminalidade é vista como um fenômeno recorrente, contínuo e consonante na sociedade.

Já algumas coberturas assinalam transgressões mais graves, circunstâncias dramáticas que saltam do pano de fundo do crime rotineiro. Para Letícia Matheus (2011), o crime mexe com uma memória do medo, que busca significações anteriores, costura os acontecimentos em notícias que não fazem sentido por si só. Sua leitura se relaciona com o extraordinário, com o melodrama e uma literatura que subsiste há séculos, que fala sobre crimes e mortes violentas, suspeitas, milagres e mistérios, de coisas que fogem a ordem:

O jornalista narra não apenas 'o que se passou efetivamente' ou explica de que forma tomara conhecimento daqueles fatos, como também transporta para o relato algo que é de certa forma previamente conhecido pelo público, ou, pelo menos, reconhecível. A bondade ou a inocência da vitima, por exemplo, podem 
vir destacadas no texto ao relembrar a sua vida. Esses aspectos são comumente construídos em oposição a maldade, à frieza, à crueldade do assassino. A composição textual se apoia em valores antagônicos e deixa um ensinamento moral insinuado (MATHEUS, 2011, p. 33).

Portanto, os relatos de crimes não são isolados, mas sim, tem uma relação com outras reportagens, em um "comunicacional mais amplo que passam a constituir uma espécie de continuum narrativo sobre o tema" (MATHEUS, 2011, p. 17, grifos originais). A notícia sobre crime constrói uma memória através de elos narrativos, remetendo aos repositório de figuras de imaginário. São personagens, representações, que transcendem a notícia em si, enredos atemporais, com um significado simbólico de atuar como modelo para a cultura, como fonte de contornos normativos, impulsionando comportamento e produzindo sanções (BIRD, DARDENE, 1993).

Assim, “cada 'estória' individual sobre crime é escrita tendo como cenário outras 'estórias' sobre o crime, às quais retiram elementos e acrescem outros [...] as 'estórias' tornam-se parte de uma 'estória' ou mito mais amplo acerca do crime e dos valores" (BIRD, DARDENE, 1993, p. 267). Muito embora cada caso tenha suas singularidades, "todo caso remete a um lugar fora dele, o lugar em que estão 'os crimes passionais' da humanidade e suas repetições. O jornalismo vive um paradoxo: conta uma novidade e mostra que ela não é tão nova assim" (BENETTI, 2012, 153).

Potter e Kappeler (1998) afirmam que a mídia, o estado e o sistema criminal criam e perpetuam mitos sobre crime, que atentam sobre grupos minoritários e desviantes da sociedade:

A mídia junto com os agentes do estado reproduz uma imagem de desordem pública que é predominantemente baseada na criminalidade de rua, especialmente por ofensas cometidas por indivíduos de baixa renda. Tipicamente, essas construções de crime também são nulas de referências de sentido para a relação causal entre crime e condições sociais. Consequentemente, a mídia contribui para uma das mais comuns formas de propaganda, nomeadamente, a criação de estereótipos criminais (WELCH; FENWICK; ROBERTS, 1998, p. 73, tradução livre ).

Hall e outros autores (1993) apontam que as escolhas das fontes jornalísticas, sobre uma hierarquia de credibilidade, acaba por priorizar as agências penais (polícia, judiciário, Ministério Público) nos casos de notícias sobre crime, o que tem como consequência a reafirmação do status quo. Os autores chamam essas fontes de definidores primários, já que também são as mesmas responsáveis pelas próprias definições de crime, o que limita o espaço para dissensos sobre a matéria criminal. Além disso, o jornalismo presta uma atenção subsidiária aos crimes comuns e de grande dano, como a criminalidade ambiental de colarinho branco, os quais, tem uma capacidade de dano sociais maiores em relação a fatos isolados, como furtos de rua ${ }^{6}$.

A ótica de Motta, de enxergar o jornalismo como narrativa, contribui para pensá-lo num sentido menos maniqueísta que o comumente defendido no senso comum que envolve crime e mídia, dividido naqueles que colocam o jornalismo em um papel de justiceiro ou os que o pintam como manipulador e puramente sensacionalista. O fato é que o jornalismo é uma prática social que não está deslocada de um sistema simbólico, nem seus agentes são imunes às estruturas sociais. Além disso, as próprias peculiaridades das condições de produção desse discurso

6 Em 1995, estimava-se que nos Estados Unidos, a criminalidade de rua custasse em torno de 4 bilhões de dólares aos cofres públicos, enquanto que o custo dos crimes de colarinho branco e dos corporativos figurava em cerca de 200 bilhões de dólares por ano. Além disso, ao passo que, aproximadamente, 24 mil homicídios são cometidos por ano nos Estados Unidos, durante o mesmo período, mais de 56 mil trabalhadores morreram graças a doenças e acidentes resultantes de condições de trabalho inseguras. (WELCH; FENWICK; ROBERTS, 1998) 
confluem para uma tendência de, no trabalho simbólico que exerce, familiarizar o estranho dentro de normas do senso comum. No caso da notícia sobre o crime, o senso comum que remete aos discursos positivistas acaba imperando:

A difusão do senso comum biológica e antropologicamente modelado a respeito da criminalidade é uma das questões de que se ocupam vários estudiosos da matéria, também da área da comunicação social. Nesse sentido, deve-se ter em conta que o próprio jornalismo é completamente fundado no senso comum, ou seja, na imagem que os jornalistas têm da sociedade e da forma como devem adaptar a sua linguagem para atingi-la efetivamente. A própria definição dos valores-notícia converge nesse sentido. Estes valores não estão codificados, sendo utilizados a partir de um certo consenso existente em torno deles (BUDÓ, 2006, p. 9).

Já quando a mulher infringe a lei, as análises ainda devem levar em conta o senso comum ancorado nos padrões de gênero de feminilidade. A criminalidade abordada pelo jornalismo costuma relatar crimes de rua, crimes contra o patrimônio e o tráfico de drogas. Embora sejam crimes também cometidos por mulheres, a sua representação jornalística, em grande parte, traz apenas agentes masculinos. A mitologia do crime construída pela mídia evidencia que este lugar de ação é um lugar do masculino, que acontece na esfera pública, com traços de violência, racionalidade e agressividade, que são atributos construídos dentro de um padrão de masculinidade hegemônica (CONNEL; MESSERSCHMIDT, 2005).

Como consequência, essa mitologia ignora que crime não é um conceito restrito nessas formas de ação, negligenciando que ele também é um fenômeno da esfera doméstica e privada, ou que não significa um conceito unívoco de violência. Portanto, conclui-se que há uma mitologia sobre crime e sobre mulher que são alimentadas e transformadas pelas representações apresentadas nas narrativas do jornalismo, as quais, serão investigadas no caso concreto abordado por esse estudo.

\section{PERCURSOS METODOLÓGICOS}

A Análise do Discurso ${ }^{7}$ é um recurso importante de investigação qualitativa (BENETTI, 2008), segundo a qual, "[o texto] é a parte visível ou material de um processo altamente complexo que inicia em outro lugar: na sociedade, na cultura, na ideologia, no imaginário" (BENETTI, 2007, p. 111). Os dizeres "são efeitos de sentido que são produzidos em condições determinadas e que estão de alguma forma presentes no modo como se diz, deixando vestígios que o analista de discurso tem de apreender" (ORLANDI, 2007, p. 30).

Os sentidos, quando produzidos, interagem com outros discursos pré-existentes, e assim, o sujeito não controla como os sentidos se constituem, pois, as palavras não são só nossas, mas têm significado pela história e pela língua (ORLANDI, 2007). Então, existe uma interdiscursividade, o interdiscurso, o conjunto das formulações já feitas e esquecidas, que como efeito, determinam uma rede de sentidos a serem apreendidos: "para que minhas palavras tenham sentido é preciso que elas já façam sentido” (ORLANDI, 2007, p. 33).

7 Tendo em vista esse aporte teórico, Márcia Benetti (2007; 2008) propõe o estudo do jornalismo através da Análise de Discurso (AD). Nas palavras de Eni Orlandi(2007), a AD se constitui nos anos 1960, a partir de três linhas - a Linguística, o Marxismo e a Psicanálise, e assim: "A Análise de Discurso, como seu próprio nome indica, não trata da língua, não trata da gramática, embora todas essas coisas lhe interessem. Ela trata do discurso, E a palavra discurso, etimologicamente, tem em si a ideia de curso, de percurso, de correr por, de movimento. O discurso é assim palavra em movimento, prática de linguagem: com o estudo do discurso observa-se o homem falando. $\mathrm{Na}$ análise do discurso, procura-se compreender a língua fazendo sentido, enquanto trabalho simbólico, parte do trabalho social geral, constitutivo do homem e da sua história" (ORLANDI, 2007, p. 15). 
Para mapear os sentidos de um texto, Benetti ensina que é preciso ir além da camada visível e material, onda há a "impressão de algo que 'natural, óbvia e evidentemente só poderia significar isto" (BENETTI, 2007, p. 108, grifos originais), assim, alcançar a camada ideológica do texto (BENETTI, 2007). A Análise do Discurso é, então um recurso metodológico que opera "refletindo sobre a maneira como a linguagem está materializada na ideologia e como a ideologia se manifesta na língua” (ORLANDI, 2007, p. 16).

Para desvendar a segunda camada do discurso, Benetti propõe como primeiro procedimento a identificação de formações discursivas (FD) "uma espécie de região de sentidos, circunscrita por um limite interpretativo que exclui o que invalidaria aquele sentido" (BENETTI, 2007, p. 112). A identificação das FDs envolve perceber que marcas discursivas giram em torno de determinados sentidos nucleares, que emergem um sentido único, e não outro (pois assim, teríamos outra formação discursiva). É na busca por recorrências de sentidos que podemos identificar determinadas filiações discursivas, então mapeadas como uma FD.

Em um segundo momento, deve-se buscar identificar nos textos que compõe o corpus as sequências discursivas (SD), "o trecho que arbitrariamente recortamos para análise e depois utilizamos no relato da pesquisa" (BENETTI, 2007, p. 123). As SDs são, de fato, as marcas textuais de uma FD, dispersas nos textos e aparentes apenas quando o pesquisador, objetivamente, busca pelos sentidos - norteado por uma questão de pesquisa. Por fim, deve-se relacionar os sentidos mapeados nas FDs com as SDs.

O objeto do estudo desse trabalho é a revista Veja, criada por Roberto Civita, em 1968, inspirado na revista estadunidense Time, criada em 1923. Atualmente, a revista tem uma circulação média de um milhão de exemplares por edição, sendo a revista de maior tiragem do Brasil. A presente pesquisa analisou a década de 2003 a 2013, buscando reportagens de capa com mulheres criminosas.

Dessa filtragem, foram encontradas quatro revistas. A primeira edição selecionada, $\mathrm{n}^{\mathbf{o}}$ 1951 de 12 de abril de 2006, traz a reportagem de capa sobre Suzane Von Richthofen, acusada de matar os pais, juntamente com o então namorado, Daniel Cravinhos e o irmão dele, Cristian Cravinhos. A manchete de Veja destacou: “Os mortos de Suzane: Às vésperas de ser julgada pelo assassinato de seus pais, Suzane Von Richthofen vive reclusa e assombrada pelo crime que chocou o país - 'Quero minha vida de volta' disse ela a Veja'. A segunda é a edição 2057 do dia 23 de abril de 2008, que estampa o casal Ana Carolina Nardoni e Alexandre Nardoni, suspeitos de jogarem a menina Isabela Nardoni, filha do primeiro casamento de Alexandre, do sexto andar do prédio em que moravam. A capa dizia: "Foram eles - para a polícia, não há mais dúvidas sobre a morte de Isabella".

A terceira edição selecionada é a de no 2166 de 26 de maio de 2010, com a manchete "A confissão da Bruxa - eu chamei a menina de cachorra mesmo". A criminosa em questão era Vera Lúcia de Sant'Anna', acusada de torturar uma menina de dois anos que estava sob sua guarda. E a quarta edição é $n^{\circ} 2273$, ano 45, no 24, do dia 13 de junho de 2012, trazia uma foto da mulher infratora: loira, branca, bonita, com a manchete: "Caso YOKI - Mulher Fatal - A história de Elize Matsunaga, assassina confessa, que esquartejou o marido milionário enquanto a filha dormia". $\mathrm{O}$ caso é o da esposa do executivo Marcos Matsunaga, Elize, de 30 anos, que foi presa no dia 5 de junho de 2012, e no dia seguinte, confessou ter assassinado o marido com um tiro na cabeça. Ela também confessou ter esquartejado o corpo e ocultado o cadáver.

As formações discursivas que nortearão a presente análise estão baseadas no estudo prévio de Jewkes, no livro "Media \& Crime" (Crime e Midia), que dedica um capítulo ao estudo das mulheres criminosas. Nele, a autora revisa casos emblemáticos de mulheres que assassinaram, abusaram sexualmente e/ou cometeram outros delitos de alta gravidade, bem como, estudos já realizados sobre o tratamento da mulher criminosa na mídia enquanto um conceito amplo. Para Jewkes, o jornalismo encontra nestas mulheres algumas das mais ricas imagens de crime e desvio, que na falta de qualquer outro discurso que explique este fenômeno, permite 
imergir em um repositório simbólico cultural que recai em representações estereotipadas e que "combinam-se para apresentar as mulheres como seres passivos e instáveis, com falhas morais, e, de alguma forma, incapazes de agir como seres humanos adultos plenos" (JEWKES, 2004, p. 113, tradução livre)".

Neste estudo, Jewkes identificou oito formas narartivas padrão (standard narratives) das quais o jornalismo lança mão ao falar de mulheres criminosas: 1) sexualidade e desvio sexual (sexuality and sexual deviance); 2) atração física (physical attractiveness); 3) condição matrimonial, como más esposas (bad wives); 4) maternidade, como más mães (bad mothers); 5) monstros mitológicos (mythical monsters); 6) "vacas loucas" (mad cows); 7) manipuladoras do mal (evil manipulators); e 8) não agentes (non-agents). Após a leitura do corpus, foram selecionadas as sequências discursivas que movimentavam os sentidos referentes a cada categoria de Jewkes.

\section{DISCURSOS SOBRE MULHER E CRIME NO JORNALISMO DA VEJA}

A primeira característica apontada por Jewkes em seus estudos sobre a representação midiática da mulher criminosa destaca o enfoque na sexualidade e no desvio sexual (sexuality and sexual deviance). Esse é um importante referente sobre os modos a partir dos quais o comportamento feminino é avaliado na sociedade contemporânea. O jornalismo tende a reconstruir o histórico sexual dessas mulheres como forma de caracterizar suas personalidades criminosas. Padrões sexuais que seriam considerados "normais" para homens são usados para caracterizar mulheres - em uma disposição, em geral, polarizada entre promíscuas ou frígidas, inexperientes.

Para Veja, o desvio sexual é um referente importante na construção do perfil criminoso das mulheres. Nas reportagens analisadas, a revista costuma sempre apontar algum traço da vida sexual das mulheres criminosas:

Depois do crime, Suzane e Daniel deixaram Cristian perto da casa dele e foram para um motel. No primeiro depoimento que prestaram à polícia, logo após o crime, os dois afirmaram ter mantido relações sexuais naquela noite. Mais tarde, mudaram a versão (SD1).

Três anos depois, durante a gravidez de Ana Carolina, Nardoni entrou na faculdade e conheceu Anna Carolina Jatobá, com quem passou a manter um romance paralelo $(\mathrm{SD} 2)$.

Uma moça bonita e pobre, nascida no interior, muda-se para a cidade grande e passa a levar a vida como prostituta de luxo, até que conhece um executivo cavalheiro, educado, herdeiro de uma empresa bilionária - e casado. Ele se apaixona por ela e, depois de três anos de envolvimento, abandona a mulher e a filha pequena para ficar com o novo amor. (SD 3).

O romance de um rico executivo que se casa com uma bela garota de programa começa como uma história de cinema e termina em tragédia (SD4)

Aos 18 anos, a moça partiu para a capital paranaense, onde fez um curso técnico de enfermagem. Chegou a trabalhar em um centro cirúrgico, mas a vida ali também não lhe pareceu interessante, e logo ela se mudou para São Paulo. São os anos mais nebulosos da sua história. A VEJA, a mãe de Elize disse não saber o que a filha fazia naquele período. O certo é que tudo se transformou quando 
ela conheceu Marcos. Depois de alguns encontros, Elize tornou-se amante do executivo. (SD5)

De volta ao apartamento, a discussão continuou. E subiu de tom. "Como você teve a ousadia de usar o meu dinheiro para colocar um detetive atrás de mim?", perguntou o marido, sem pedir desculpas. "Vou te mandar de volta para o lixo de onde você veio" (SD6).

"Você é fraca, não vai ter coragem de atirar. Vou mandar te internar. Não vou deixar minha filha ser criada por você. Nenhum juiz vai dar a guarda a uma prostituta", ameaçou Marcos (SD7).

A SD1, sobre Suzane, traz uma informação contraditória, aparentemente irrelevante para a materialidade do crime, mas leva a crer que a crueldade da personagem seria tanta ao ponto de transar com o assassino de seus pais logo após o crime. As SD2 e SD3 não deixam escapar aos olhos do leitor que as mulheres em questão, Anna Carolina Jatobá e Elize Matsunaga, se envolveram com homens casados. São contadas como 'destruidoras de lares', como mulheres que seduziram homens e os tiraram de suas legítimas esposas. Na SD3 esta descrição é ainda mais evidente por que deixa claro que é Marcos quem se apaixona por Elize, sem nem cogitar a possibilidade dela nutrir sentimentos por ele, e que é esta paixão que o faz abandonar a esposa a filha do primeiro casamento. No caso de Elize, a caracterização do desvio sexual é notada com mais evidência, pois ela trabalhava como garota de programa quando conheceu Marcos (SD3; SD4; SD6; SD7). A SD3 marca a mudança do eixo da vida de Elize: moça bonita e pobre do interior, para a prostituta de luxo da grande cidade. A partir da SD5, percebemos que o enunciador deixa claro que ela exercia uma profissão "digna", de técnica de enfermagem, mas optou pela prostituição. Esta sequência não explora quaisquer que fossem as razões de Elize ter entrado para a prostituição, apenas afirma ter sido uma opção hedonista, em busca de uma vida interessante como prostituta de luxo.

Três das quatro reportagens analisadas se valem deste recurso discursivo ao traçar os perfis das mulheres criminosas. Para construir a mulher como agente de criminalidade, é preciso desenvolver um juízo de marginalidade e depravação. Para esta construção, o recurso do desvio sexual é bastante eficiente, pois a cultura patriarcal tem grande preocupação com o controle da sexualidade feminina, formando juízos negativos sobre comportamentos considerados desviantes. Trazer para a esfera pública o conhecimento sobre a vida sexual de uma mulher também funciona como uma punição simbólica, que cria estigmas e gera possíveis consequências para esta mulher.

Outro padrão narrativo descrito por Jewkes e também observado entre as estratégias narrativas de Veja é a atração física (physical attractiveness). Jewkes (2004) ${ }^{8}$ afirma que a atração física, ou uma "competência de sedução feminina", serve, sistematicamente, como um agravante do desvio feminino".

\footnotetext{
8 Jewkes lembra diversos casos de mulheres criminosas que foram caracterizadas a partir desse "perfil" peculiar de desvio. Entre os exemplos, o caso de uma criminosa norte-americana descrita como uma mulher de "traseiro e coxas enormes" (huge buttocks and thighs). Outras definições descritas por Jewkes foram: da mulher descrita como "terrível aos olhos do marido", e, ainda, de uma ex-modelo acusada do assassinato do namorado, descrita como "excessivamente maquiada", "vaidosa", e - como salientou uma manchete, com fotos suas - que tinha um "olhar que pode matar" (looks that could kill). O jornalismo reitera esse lugar comum que valoriza atributos femininos como juventude e beleza para a contemplação masculina ou que retrata a mulher bonita como "mulher fatal" ("femme fatalle"), que seduz as vítimas, e que possui um olhar que pode matar.

9 Ao tipificar as características físicas que o criminoso homem possuía, Lombroso associava a delinquência à feiura. No entanto, quando o objeto de sua pesquisa foi a mulher, associou a beleza à capacidade de dissimulação e manipulação da criminosa (LOMBROSO e FERRERO, 1903).
} 
Uma moça bonita e pobre, nascida no interior, muda-se para a cidade grande e passa a levar a vida como prostituta de luxo, até que conhece um executivo cavalheiro, educado, herdeiro de uma empresa bilionária - e casado. (SD8).

O romance de um rico executivo que se casa com uma bela garota de programa começa como uma história de cinema e termina em tragédia (SD9)

As fotos bem produzidas da mulher loira, de traços delicados, corpo sinuoso e codinome Kelly chamaram a atenção do jovem executivo de ascendência japonesa (SD10).

O apelo ao padrão narrativo que explora a aparência física é bastante evidente em Veja, especialmente, enquanto traça o perfil de Elize. A própria capa da revista já mostra o propósito da reportagem: construir o perfil de uma mulher fatal, bela, sedutora e capaz de matar. A aparência da personagem é ressaltada nas já citadas SD3 e SD4, e também na SD10.

No entanto, em outras situações, algumas descrições físicas são feitas com o intuito de instituir um outro lugar para a mulher: a aparência serve de recurso para narrar a mulher como "não feminina", "robusta", "não natural", "feia". Essa estratégia narrativa pretende rebaixar a aparência da mulher:

Mais gorda, com os cabelos curtos e uma franja cobrindo parte dos olhos, ela recebeu a reportagem de VEJA com os cabelos desalinhados, calçada em pantufas e vestindo uma camiseta cor-de-rosa com estampa da personagem Minnie (SD11).

Deixou de praticar esportes e trocou as blusas justas e curtas que gostava de usar por camisetas largas e compridas (SD12).

Nesse contexto, os sentidos relacionado à aparência são reunidos em torno da descrição da perda da vaidade. Suzane seria uma moça vaidosa, bonita como qualquer adolescente, porém, perde esta vaidade após o crime, engordando e usando roupas largas. O discurso da Veja está baseado em um padrão de beleza, no qual, a mulher, para ser visualmente agradável, deve conformar algumas características: ser loira, de traços delicados e corpo sinuoso (SD10), como Elize. Já o desleixo, as roupas largas e o ganho de peso, características de Suzane, são o oposto.

A mulher criminosa também é narrada segundo sua condição matrimonial (bad wives). A condição de boa esposa é uma condição de respeitabilidade. Para Jewkes (2004), a violência masculina ou feminina é representada dentro de um enquadramento no qual "famílias tradicionais e conservadoras e relações de gênero são reiteradas e celebradas, mesmo quando a realidade de muitos dos crimes [...] indicam famílias e casamentos como lugares de violências (majoritariamente masculinas), abuso sexual e assassinato" (JEWKES, 2004, p. 121, tradução livre)

Nas SD2 e SD3, trabalhadas no item sobre desvio sexual, as personagens de Elize e Anna Carolina são lembradas por terem sido amantes. Aqui, estas sequências também colocam em questão a respeitabilidade destas mulheres enquanto esposas e como sujeitos nocivos à família tradicional. Quanto à Elize, a narrativa se esforça em construir Marcos como o marido perfeito, a exemplo das seguintes sequências:

Os que conviveram com os dois nesse período descrevem Marcos como um homem "à moda antiga". Abria a porta do carro para Elize e levantava-se da mesa para puxar-lhe a cadeira até quando ela ia ao banheiro (SD13). 
Nunca lhe faltou dinheiro, mas ela também não era de esbanjar. Tinha uma Pajero TR4, presente de Marcos, e gostava de jóias e bolsas (SD14).

Com a madrasta de Isabella, Nardoni sempre teve uma relação tumultuada. Amigos e vizinhos relatam episódios de ciúme e agressão entre os dois. Se Nardoni tinha fama de briguento, Anna Carolina é freqüentemente descrita como "esquentada". Algumas vezes, era ela quem começava a bater no marido, segundo afirmaram à polícia vizinhos do prédio em que o casal morou antes de se mudar para o edifício em que Isabella morreu. Anna Carolina, ela própria, não vinha de uma família que se poderia chamar de harmoniosa. O pai, Alexandre Jatobá, responde a nove processos na Justiça (a maioria por não pagamento de dívidas e um por furto de energia). Em duas ocasiões, em 2004 e 2005, a própria Anna Carolina prestou queixa à polícia contra o pai por lesão corporal, injúria e ameaça. Um ex-empregado de uma loja de carros que Jatobá teve em Guarulhos descreve o ex-patrão como "um homem muito nervoso" (SD15).

Casada duas vezes (uma delas com seu atual advogado, Jair Leite Pereira), Vera Lúcia optou por não ter filhos. Mas de seis anos para cá andava obcecada pela ideia de adotar uma criança (SD16).

Elize retribuiu a perfeição do marido demonstrando estar ajustada a sua nova condição: de esposa e mãe. Entre as características mais salientes desse ajustamento, está a SD13, em que o enunciador a descreve como "responsável" com o dinheiro do marido milionário - afinal, ela não era de esbanjar.

Em contrapartiada, o enunciador trata o casamento de Alexandre e Anna Carolina como uma relação conturbada. Alexandre tinha fama de briguento (SD 14), algo passível de desconfiança, pois é algo incerto, que se forma a partir de fofocas e boatos. Já Anna Carolina é frequentemente descrita como "esquentada", com juízo de certeza, com mais força de verdade do que a fama de Alexandre. Em seguida, o enunciador fala apenas do quanto Anna Carolina era "desestabilizada", sem pontuar exemplos sobre o marido, fazendo crer que era ela quem tinha mais responsabilidade pelas brigas. Na SD16, o enunciador lembra que Vera Lúcia foi casada duas vezes. Embora hoje as pessoas escolhem se casar por afeição ao parceiro ou parceira, alguns estereótipos ainda são latentes na cultura, como a divorciada e a solteirona.

Além desses padrões, a maternidade (bad mothers) é levada em conta, nos estudos de Jewkes (2004), principalmente em relação aos crimes envolvendo crianças. Para a autora, o ideal materno serve para desqualificar as mulheres como más mães, ou ainda, para reduzir a "humanidade" daquelas que não têm filhos. Este ponto é bastante explorado nos casos estudados:

Nenhum vizinho diz ter ouvido o estampido. A filha pequena dormia no quarto (SD17).

Passará um longo tempo na prisão, sem direito à herança e sem saber o que será do futuro da filha (SD18).

No caso de Matsunaga, e de modo a construir esse sentido de uma mãe incompetente, Veja lembra que Elize teria matado o marido enquanto a filha dormia no quarto ao lado (SD17). Já na SD18, afirma que Elize não saberá o que vai ser do futuro da filha, como se a condição de mãe fosse um direito relativo, como a herança.

Para Anna Carolina Jatobá, ser a madrasta dispensa demais caracterizações, pois esta palavra, que aparece 8 vezes no corpo do texto, já aciona o imaginário de tantas histórias que 
envolveram tais personagens. A reportagem de Veja tenta ressaltar o seu lado mais sombrio enquanto mulher e mãe:

E a mulher, que também em carta afirmou ser a criança "tudo" na sua vida, ajudou a matá-la com as próprias mãos (SD19).

O primeiro dá conta de que Anna Carolina, em meio a uma discussão com o marido, motivada por ciúme, "jogou sobre a cama" o filho Cauã, de 11 meses, antes de partir para cima de Nardoni, furiosa (SD20).

A polícia tenciona pedir a prisão preventiva de Nardoni e Anna Carolina. Se condenados ao final do processo, a morte de Isabella não será a única $e$ aterradora culpa que carregarão. Eles são pais de duas crianças, cuja vida estará para sempre marcada pelas cenas a que elas - muito provavelmente assistiram aterrorizadas (SD21).

Pelo que foi possível reconstituir do crime até agora, a polícia acredita que Pietro assistiu a boa parte dos episódios que resultaram na morte da irmã (SD22).

Por outro lado, quando fala da mãe biológica de Isabella, Ana Carolina de Oliveira, traça um paralelo: é a mãe incansável, trabalhadora, inconformada com a morte da filha, que é forte, quer justiça mas que fenece às emoções, em oposição a Anna Carolina Jatobá, que bate nos filhos, é esquentada e matou Isabella.

Ao longo do inquérito que investiga o assassinato de Isabella, a delegada Renata acabou ficando próxima de Ana Carolina Oliveira, que lhe telefona todas as noites para saber do andamento das investigações sobre a morte da filha. Nessas ligações, Ana Carolina, que poucas vezes foi vista chorando em público, cai freqüientemente em prantos (SD24)

"Ela disse que Ana Carolina apanhava coisa por coisa: até uma presilha da menina que estava caída na garagem", disse a amiga. Rosa contou ainda que se sente aflita pelo fato de Ana Carolina "não se abrir com os pais e os irmãos" (SD25)

Ana Carolina, que é bancária, já voltou a trabalhar. Por iniciativa da sua chefia, ela foi temporariamente afastada dos serviços de atendimento ao público e está incumbida de atividades administrativas. Entre 2004 e 2006, a mãe de Isabella estudou na Universidade Nove de Julho, onde se graduou no curso de formação específica em administração de recursos humanos. Durante o curso, além de trabalhar em empresas da área, ela vendia roupas e bijuterias para reforçar o orçamento (SD26).

Quando fala de Vera Lúcia, a mulher acusada de maus tratos contra uma menina de 5 anos que pretendia adotar, Veja destaca que a ex-procuradora não tinha filhos por opção e que a única preocupação que a levava a querer adotar era quanto à sua herança e pensão. Além disso, ela é a mulher que não tem filhos, que se choca diretamente à "lei natural" de que elas têm o dever e a função de reprodução e perpetuação da espécie.

Seu objetivo declarado era ter a quem deixar sua pensão como procuradora, hoje de 23000 reais, e os bens, entre os quais uma casa debruçada sobre a valorizada 
Praia de Geribá, em Búzios. Esse tipo de argumento normalmente desqualifica o candidato à adoção por não traduzir um desejo genuíno de maternidade (SD27).

O quinto padrão citado nos estudos de Jewkes pode ser descrito a partir da figura dos monstros mitológicos (mythical monsters), como a Medusa, Medea, bruxas, vampiras e satanistas, que constroem as mulheres criminosas como seres da mitologia pagã, Judaico cristã e da literatura clássica. São noções tão intrínsecas no imaginário popular que criam caricaturas midiáticas, nas quais se torna difícil enxergar essas mulheres senão como criaturas grotescas.

Ao falar da construção de Anna Carolina Jatobá como a madrasta má, já observou-se um exemplo deste padrão narrativo. Na reportagem sobre Suzane, o enunciador traça um outro caminho mitológico para descrever o crime. Primeiramente, ele remete a punição dos crimes de matar pai e mãe às leis da Roma Antiga, como vemos na SD28:

O parricídio e o matricídio são crimes repudiados com horror por todas as épocas, etnias e sociedades. Na Roma Antiga, os homicídios eram punidos de diferentes maneiras, dependendo de sua gravidade. Nessa escala, o assassinato do pai pelo filho merecia a mais espetacular das punições. A Lei Pompéia sobre os Parricídios, criada em 55 a.C., dizia que aquele que matar seu ascendente não deverá ser submetido "nem à espada, nem ao fogo, nem a nenhuma outra pena solene". Deverá, no lugar disso, ser "encerrado em um saco de couro, juntamente com um cão feroz, um galo, uma víbora e uma macaca, e, nessas fúnebres estruturas, ser arrojado ao mar vizinho ou ao rio, para que em vida lhe cheguem a faltar todos os elementos, e, enquanto viva, seja privado da luz do céu, e, uma vez morto, da terra" (SD28).

Na sequência, não faz nenhuma colocação sobre a lei atual ou que as formas de punição mudaram. Essa parece uma estratégia de justificar a grande espetacularização do caso, ou de justificar um punição rigorosa, pois o enunciador não faz qualquer alusão às mudanças nas formas de punir. Depois, o enunciador relaiciona o crime de Suzane a uma versão reducionista do complexo de Édipo:

A peça Édipo Rei, escrita por Sófocles, tornou-se a mais famosa tragédia grega justamente por tratar desse crime tremendo que é o parricídio. A obra inspirou o pai da psicanálise, o austríaco Sigmund Freud, a tomar o nome de Édipo emprestado para designar o complexo que está na base do psiquismo e das neuroses: o desejo recôndito do menino pequeno de matar o pai, visto como rival amoroso em sua relação com a mãe, assim como o da menina pequena de eliminar a mãe. Eis por que o parricídio e o matricídio assombram tanto por serem crimes que, ao atentar contra um dos pilares da civilização, a família, ecoam uma essência humana atávica e incancelável. Quando ganham materialidade por decisão de uma menina que poderia ser a filha de qualquer um de nós, como Suzane, o horror aumenta. Tende-se, inclusive, a buscar uma explicação razoável para a atrocidade algo que distancie a tragédia de nossas vidas, que nos dê a certeza de que só poderia acontecer com "eles". Foi assim no caso de Suzane (SD29).

Os contos de fadas, cujos heróis enfrentam bruxas malvadas e lobos maus, inevitavelmente acabam bem. São uma forma de as crianças encararem e exorcizarem seus medos e angústias, dizem os psicanalistas. Mas, só no Brasil, há milhares de meninos e meninas que descobrem, desde muito cedo, que bruxas malvadas e lobos maus podem existir de verdade - e, pior, habitar a casa onde eles moram. A procuradora aposentada Vera Lúcia de Sant'Anna Gomes, de 66 anos, é uma dessas bruxas malvadas de carne e osso. (SD30) 
Depois que se aposentou, doze anos atrás, a procuradora passou a preencher $o$ tempo com os animais de estimação (tem um poodle e dois gatos siameses), viagens de cruzeiro para o Nordeste e o tarô, que costumava jogar na internet para colegas de comunidades virtuais chamadas, nem tão ironicamente no seu caso, Caldeirão, Vassoura e Intuição e Magia Prática. Na denúncia contra ela encaminhada à Justiça consta a suspeita de que faria parte de uma seita satânica. Uma testemunha conta que viu, em seu apartamento de 200 metros quadrados, no bairro de Ipanema, Zona Sul da cidade, vodus e bonecos com rosto desfigurado, ladeados por imagens de Buda e uma coleção de 150 baralhos de tarô. Era ali que a procuradora costumava ficar reclusa. Diz o seu sobrinho Carlos Ariosto: "Ela é tão fechada que não chegou nem a apresentar à família a menina que iria adotar". (SD31)

Apesar da bruxa processada, não é um final de conto de fadas. (SD32)

O conto de fadas é um recurso do imaginário bastante utilizado pelo enunciador no caso de Vera Lúcia (SD30 e SD3). A reportagem constrói a imagem perfeita de uma bruxa real, "de carne e osso": vive sozinha e reclusa, tem cabelos longos e grisalhos (SD16), frequenta comunidades virtuais com os nomes "Caldeirão", "Vassoura" e "Intuição e Magia Prática". Além disso, mistura diversos elementos da iconografia religiosa que não é judaico-cristã para falar que Vera praticava magia negra, mesmo que Budas não tenham relação com nenhuma seita satânica. O elemento do conto de fadas também aparece na reportagem sobre Elize Matsunaga:

Para Elize, o conto de fadas terminou. Para a família de Marcos, restaram as imagens de um filme de terror (SD33).

Além do título da reportagem que já se refere aos contos de fadas, toda narrativa é constrída como se Elize fosse a gata borralheira (SD3), uma menina humilde que ascende socialmente através do casamento, e Marcos, o príncipe encantado (SD13 e SD14). Dessa forma, a narrativa mitológica, enquanto recurso metafórico, busca figuras no imaginário popular para contar estas histórias e atribuir significados.

Jewkes (2004) defende que, para a sociedade, é muito mais fácil aceitar que o crime tenha sido cometido por um afeto psicológico, histérico, ou por aspectos psicopatológicos peculiares das mulheres, comparando-as a "vacas loucas" (mad cows). Essa sétima categoria que a autora elenca, descreve mulheres taxadas como 'psicóticas' ou 'psicopatológicas', que passam a vida em prisões e instituições mentais, ou são medicadas com produtos que as tornam dependentes químicas por toda a vida.

A monstruosidade da procuradora é identificada por especialistas como típica dos psicopatas. Eles são capazes de entender intelectualmente a diferença entre o bem e o mal, mas não demonstram ter aquelas emoções que estão na base do senso moral das pessoas - como ilustra o caso de Vera Lúcia (SD34).

O que explica crime tão brutal? Embora seja impossível dizer com precisão, especialistas citam um distúrbio psiquiátrico, a catatimia, que se manifesta quando alguém fica remoendo obsessivamente um trauma afetivo, como uma traição, e desenvolve um plano que tem a violência como componente essencial. Alguns comportamentos de Elize podem ser definidos como catatímicos. Mas não todos (SD35).

Nesses casos, fala mais alto a espessa zona de mistério que envolve o cérebro adolescente, uma sopa fervente de hormônios, sensações, ansiedade, dúvidas e 
desejos. Os dois adolescentes americanos Eric Harris e Dylan Klebold não eram muito diferentes dos outros, até que, em 1999, mataram a tiros colegas e professores na escola, o que ficou conhecido como Massacre de Columbine. Por que isso ocorreu? Nunca se saberá ao certo (SD36).

Neste caso, o enunciador pode utilizar do comportamento anti-social, como o que caracteriza o psicopata para explicar o crime cometido, tal qual o faz na SD34, ao falar de Vera Lúcia. Em outros casos, busca a explicação em outros distúrbios psicológicos, como a suposta catitimia de Elize (SD35), ou em outras explicações biopsicológicas como a fase de transição da adolescência, na SD36, quando compara o possível estado psicológico de Suzane ao cometer o crime, com os adolescentes autores do Massacre de Columbine.

Outros dois padrões de representação da mulher criminosa, observados por Jewkes (2004), são as manipuladoras do mal (evil manipulators) ou não agentes (non-agents). No caso das primeiras, a mulher é a responsável pelo crime, que em geral foi premeditado, e manipula seu(s) parceiro(s) e vítima(s) até a consumação. Já o segundo padrão é a negação de que a mulher pode também ser violenta, sádica e cruel. Elas não são agentes de suas condutas, mas levadas ao ato criminoso enquanto manipuladas por emoções, pessoas e condições sociais abusivas (como a violência doméstica).

É interessante perceber que o enunciador oscila entre estes dois estereótipos, por vezes conflitantes. Na SD35, Elize poderia estar agindo enquanto não agente, devido ao afeto psicológico da catitimia, mas o enunciador destaca que nem todos seus atos foram irracionais. Nas SD37, SD38, SD39 e SD40, o enunciador deixa claro que Elize era como uma esquartejadora profissional, tinha destreza, planejamento, conhecimentos de anatomia, perseverança e sangue frio para esquartejar o marido. Todas estas habilidades, segundo o texto, advém do curso de auxiliar de enfermagem: um curso de nível médio, voltado para cuidados ambulatoriais que provavelmente teria pouca ênfase em anatomia cirúrgica.

Esquartejar alguém é uma tarefa que requer força, paciência e destreza. Elize Matsunaga demonstrou ter tudo isso - e ainda capacidade de planejamento, no que a ajudaram os conhecimentos de anatomia adquiridos no curso de técnica de enfermagem, feito em Curitiba, antes de se mudar para São Paulo (SD37).

Ao que tudo indica, Elize sabia onde os cortes deveriam ser feitos de modo a facilitar seu trabalho, realizado com uma faca de lâmina de 30 centímetros (SD38).

Para chegar até as articulações, Elize teve de cortar primeiro pele, músculos, tendões e ligamentos. Segundo os médicos-legistas, o mais difícil nesse processo é o rompimento dos ligamentos, estruturas formadas por fibras tão resistentes quanto tiras de couro (SD39)

Elize Matsunaga levou quatro horas para esquartejar o marido. Alguém sem os seus conhecimentos anatômicos levaria, no mínimo, seis (SD40)

Suzane também oscila entre não agente e manipuladora. Na SD41 ela é manipulada e perdida, uma menina com medo. No entanto, ao longo da narrativa da reportagem, ela é também agente da manipulação, cúmplice de uma encenação. Na SD42 e na SD43, ela é como uma criança que assiste desenhos. Mas na SD44, o enunciador tem certeza que Suzane foi instruída para encenar um personagem frágil, pois é Suzane quem tenta convencer. Se restasse alguma dúvida sobre a capacidade de dissimular de Suzane, na SD45, o enunciador contradita a versão dela, de que chorou durante o crime, afirmando que ela teve "suficiente sangue-frio" para pensar estrategicamente um assalto. 
Repudiada pela família, sem dinheiro, com medo de sair às ruas e manipulada pelos advogados, a jovem que participou do assassinato dos pais está mais perdida do que nunca (SD41).

À tarde, assiste a TV à desenhos animados são seus programas preferidos $\mathrm{e}$ brinca com os seis pássaros que a família que a hospeda cria soltos no apartamento (SD42).

Agarrada à mulher o tempo todo, comporta-se como se fosse uma criança pequena. Fala baixo e com voz infantil (SD43)

Ao responder às perguntas, escondia o rosto atrás dos cabelos, mirava o chão e lançava olhadelas indagativas para seus advogados. Claramente foi instruída por eles para fazer o tipo frágil e desassistida. No esforço de evitar o que mais teme, a volta para a cadeia, onde ficou por mais de dois anos, Suzane tenta convencer seus interlocutores de que é uma menina perturbada e que foi essa condição que a fez, em 2002, abrir a porta de casa para que o então namorado, Daniel Cravinhos, acompanhado do irmão, Cristian, entrasse no quarto de seus pais e os assassinasse a golpes de barras de ferro (SD44).

Suzane afirma que, na maior parte do tempo, chorou, com os ouvidos tampados com as mãos. Teve, no entanto, suficiente sangue-frio para espalhar documentos e contas a pagar pelo chão da biblioteca, também ajudou os irmãos a arrombar, com uma faca, a maleta em que o pai escondia dinheiro e a colocar 8000 reais e 5000 dólares na mochila de Cristian. Embora soubesse o segredo da pasta, Suzane deduziu que o arrombamento daria mais veracidade à farsa (SD45).

Chama atenção outras duas sequências. Na SD46, o delegado descreve Suzane como fria, calculista e impetuosa na época do crime. O enunciador parte do pressuposto que, de acordo com o comportamento que Suzane apresenta ao longo da matéria, algo mudou, pois Suzane se porta como uma criança meiga e que precisa de atenção. No entanto, na SD47, ele afirma "com toda certeza", "porém", ou seja, certamente há uma contradição ao fato que Suzane mudou - pois "ela pode estar usando as características descritas pelo delegado em 2002 para criar, sob a orientação dos advogados, uma persona vitimizada, carente e merecedora de pena". Mas o enunciador se esquiva do papel de juiz, pois mesmo após afirmar com toda certeza o seu juízo de valor sobre o comportamento de um indivíduo, ele afirma: não se pode prejulgar.

Será preciso convencer o júri de que Suzane não é a mesma pessoa que em 2002 foi descrita pelo delegado Domingos de Paulo Neto, que dirigia o Departamento de Homicídios e Proteção à Pessoa de São Paulo quando do duplo assassinato: "Ela é fria, calculista e impetuosa". O que mudou? (SD46)

Com toda a certeza, porém, ela pode estar usando as características descritas pelo delegado em 2002 para criar, sob a orientação dos advogados, uma persona vitimizada, carente e merecedora de pena. Não se pode prejulgar. Um júri será convocado com a específica finalidade de decidir o destino de Suzane (SD47).

A partir dessas sequências, em geral, a percepção da mulher enquanto manipuladora prevalece sobre a percepção enquanto vítima ou não agente. Em Elize, ressalta-se que ela é sujeito ativo e consciente do crime, agindo com racionalidade e manipulando as evidências. Em Suzane, há duas forças de manipulação: ela seria manipulada por advogados e outros 
interessados; mas, ela é o sujeito ativo das ações: é Suzane quem afirma, é Suzane quem chora e encena, e, para o enunciador, Suzane sabe exatamente o que está fazendo (SD47).

Retomando os casos analisados, Elize Matsunaga é personagem sobre a qual mais aparecem os padrões narrativos de Jewkes (2004). A história de Elize é recheada de elementos que permitem a utilização de recursos discursivos, os quais movimentam o imaginário do leitor e dialogam com a cultura popular. A revista Veja faz desses elementos o fio condutor da narrativa, recontando a história da "gata borralheira", Elize, e o "príncipe encantado", Marcos. Mas no final, prevalece o caráter negativo da ex-prostituta, que não valoriza nem a vida de riqueza, o bom casamento e a família que construiu. Da narrativa de Veja, parece que a pistola que efetuou o disparo não é a única arma de Elize. Sua a beleza, sedução e conhecimentos profissionais são também artifícios da consumação do crime, pois aparecem como habilidades de Elize que foram essenciais para o sucesso do assassinato. Já a sua vida sexual e sua capacidade psicológica surgem como elementos negativos de caráter que explicariam o porquê do crime e reforçam a tese da autoria.

Nos casos restantes, mesmo remetendo aos sentidos de mais de uma forma narrativa, trazem predominâncias. A reportagem sobre Suzane parece se preocupar essencialmente em desmentir as suas supostas mentiras e destacar seu caráter manipulador. O enunciador faz um caminho, traçando um perfil de Suzane como uma garota ingênua, frágil e vulnerável. Porém, a partir da SD44, o jogo vira e o enunciador passa a desconstruir este caráter e mostrar que Suzane sabe o que faz, está encenando uma personagem com o explícito intuito de dissimular a mídia, o Tribunal do Júri e toda a sociedade por ele representada.

Já no caso de Anna Carolina Jatobá, a narrativa padrão mais evidente é sobre a maternidade da personagem. Por ser a madrasta e ter seu perfil posto em contraposição com o da mãe de Isabella, Ana Carolina Nardoni. Enquanto esta é descrita como a mãe guerreira e que amava incondicionalmente a filha, Anna Carolina Jatobá tem sua personalidade narrada a partir de relatos de instabilidade e agressividade.

O caso de Vera Lúcia também é icônico em relação à categoria dos monstros mitológicos, pois, os elementos da narrativa conduzem para a figura imaginativa da bruxa: a aparência de Vera Lúcia, com cabelos grisalhos e longos, o seu gosto por misticismo e a vida reclusa, sem esposo e filhos. Além disso, a conduta criminosa de tortura a uma criança indefesa remete às bruxas que assavam, comiam, castigavam crianças, construindo uma imagem que retumba nas narrativas cristalizadas no imaginário.

Por fim, com diferentes ênfases, as oito formas narrativas estudadas por Jewkes também aparecem na construção feita pela Veja sobre as mulheres criminosas brasileiras, operando como explicação para o crime ou como indício que comprova a autoria do delito. $\mathrm{O}$ fato de Elize ter sido prostituta traz a imagem de que seu caráter é pernicioso e volúvel, capaz de condutas antissociais e criminosas. Na representação de Anna Carolina, ela não tem espírito maternal, e então, incidir no assassinato de uma criança é uma conduta encaixável. A personagem Vera Lúcia é a bruxa má, que no final dos contos, das fábulas e dos mitos, acaba processada, queimada e derrotada. Suzane, dissimulada, manipuladora e louca, é capaz de cometer parricídio e matricídio. Este texto jornalístico compõe uma narrativa maior, sobre crime e sobre mulher, que reflete outros mitos e contos cujos valores estão vivos no imaginário cultural sobre o certo e o errado, sobre o descontrole da figura feminina e sua necessária custódia.

\section{CONSIDERAÇÕES FINAIS}

Na seara da criminologia, discute-se que o sistema de justiça criminal trata das mulheres segundo valores patriarcais, questionando os juízos misóginos que elas são submetidas ao longo dos processos de criminalização e vitimização e as imunizações às diferentes formas de violência que sofrem. Por trás das agências de controle - tanto sistema de justiça quanto agências mais 
informais, como os meios de comunicação - estão padrões normativos de feminilidade e masculinidade. A perspectiva feminista enfrenta o desafio de encarar essas processos através do desenvolvimento de uma ótica de gênero, o que leva a concluir que o controle social, nas suas mais variadas formas, sempre foi uma presença forte e punitiva na vida das mulheres.

Do leque diverso de questões levantadas pelo encontro da epistemologia feminista e da criminologia, esse trabalho optou por estudar as representações jornalísticas das mulheres que violam a lei penal. De acordo com o exposto, a população feminina selecionada pelos processos criminalizadores no Brasil é composta por mulheres negras e pobres, envolvidas no tráfico de drogas ou que cometem crimes contra a propriedade. Desses dados, diferentes hipóteses surgem na pesquisa criminológica que constituem fragmentos que podem ajudar a compor um cenário interpretativo mais claro desse problema social complexo, que reflete tanto a precarização das vidas das mulheres no patriarcado, quanto as marcas de seletividade racistas e classistas do sistema penal.

Os meios de comunicação tem sistematicamente negado o enfrentamento sobre a realidade penal no Brasil. O inchaço do sistema, sua seletividade, ineficácia e insidiosa violação de direitos humanos são negligenciados em troca da prevalência de discursos maniqueístas sobre classes perigosas. Isso, abafa a urgência por alternativas reais, com foco na preservação das garantias individuais e em programas humanitários de enfrentamento de crimes (incluindo aqueles cometidos por agentes estatais).

Um exemplo dessa negligência é o encontrado nessa pesquisa. As mulheres desenhadas pela revista Veja como personagens de crimes são mulheres brancas, de classe média, com formação em curso superior e que cometeram crimes graves, com requintes de crueldade. A problemática social ressaltada anteriormente, por mais interessante, relevante e noticiável que seja, parece invisível aos olhos da notícia - ou pelo menos o é nas publicações da revista Veja. $\mathrm{Na}$ verdade, essa problemática acaba maquiada pela espetacularização de casos específicos e emblemáticos, cuja cobertura se limita à estereotipificação destas mulheres em caricaturas quase grotescas de seres humanos.

Os recursos discursivos utilizados pela revista Veja se assemelham muito às maneiras pelas quais os autores de teorias misóginas sobre criminalidade feminina descreviam as mulheres que estudavam. Mesmo após décadas de movimento feminista e de questionamento aos paradigmas deterministas, as narrativas do medievo e do enfoque positivista ainda estão latentes no imaginário popular e são reiteradas pelo discurso jornalístico.

O jornalismo tem responsabilidade na manutenção de um universo limitado de possibilidades para meninas e mulheres. Se a notícia se assemelha aos mitos, pois auxilia a perceber o mundo e delinear contornos de valores morais, ela atua no jogo entre diferente e comum, entre desconhecido e conhecido, trabalhando para a conformação ou rejeição de novas perspectivas. Sobre a mulher criminosa, o jornalismo não traz o novo, não explora a possibilidade de exposição das complexas mazelas da sociedade. Ele se ancora nos limites e constrangimentos da construção da notícia para falar o Mesmo.

A representação da mulher criminosa exerce uma forma de controle social ao valorar, para além da conduta, aquelas condutas que são percebidas, dentro do sistema patriarcal, como desviantes. As quatro personagens analisadas são representadas como detentoras de um caráter degenerado e de características que saltam aos olhos: não se enquadram nos papéis de mães e esposas, tem sua beleza e sanidade avaliada e sua vida sexual julgada como parte do crime que cometeram. Estes processos de avaliação e valoração que estas mulheres sofreram pelo discurso jornalístico, no entanto, ultrapassam as páginas das edições analisadas. Eles ocorrem com qualquer uma, nas ruas, nas escolas, nos ambientes de trabalho, na academia ou nas rodas de amigos.

A sociedade exerce uma cobrança sobre as mulheres para conformar um padrão de gênero, operando através de elementos simbólicos, de forma tácita e muitas vezes inconsciente. 
Nesse sentido, falar das criminosas é falar do feminino como um todo. Disse Simone de Beauvoir que não se nasce mulher, torna-se. Dando um passo maior, não se nasce criminosa, torna-se. $\mathrm{O}$ desvio não é etiológico, ele é consequência da dominação de um grupo social que impõe regras e atribui estigmas. Para a mulher, seus comportamentos supostamente desviantes são produto do patriarcado e da construção social do seu corpo como dotado de gênero.

O jornalismo investiga, acusa e condena nos poucos minutos ou linhas da reportagem, e quando o faz, não julga com imparcialidade, contraditório, ampla defesa ou baseado em indícios de autoria e materialidade. A estratégia é quase inquisitorial e a investigação invade a personalidade da acusada quando os traços de desvio dos padrões de gênero são descritos como indícios de dolo ou culpa. Ao fim deste processo, mulheres criminosas são duplamente punidas: pelo crime que cometeram: pela a violação de uma norma penal do Estado, e por ser mulher, por não terem cumprido com a suposta lei natural que delimita os papéis de feminino.

No final, restam as bruxas processadas e queimadas. Como pena, o label de criminosa não é o único atribuído. Ao lado estão os estigmas de louca, de histérica, de madrasta, de bruxa, de prostituta e tantas outras caracterizações que por toda uma existência acompanharão Suzane, Anna, Vera, Elize e inúmeras outras mulheres, cuja diversidade e complexidade ainda são incompreensíveis para muitos olhares.

\section{REFERÊNCIAS}

ALIMENA, Carla Marrone. A Tentativa do (Im)Possível: Feminismos e Criminologias. Rio de Janeiro: Lumen Juris, 2010. .

ANDRADE, Vera Regina Pereira De. PELAS MÃOS DA CRIMINOLOGIA - O controle penal para além da (des)ilusão. Rio de Janeiro: Revan, 2012. .

BARATTA, Alessandro. Criminologia crítica e crítica do Direito penal: introdução à sociologia do Direito Penal. 3a ed. Rio de Janeiro: Revan, 2002. .

BENETTI, Marcia. Análise do Discurso em Jornalismo: estudo de vozes e sentidos. In: LAGO, Cláudia; BENETTI, Marcia (org.). Metodologias de pesquisa em jornalismo. Petrópolis: Vozes, 2007

BENETTI, Márcia. A apropriação discursiva da morte pelo leitor. P. 149- 168 iN: MAROCCO, Beatriz, BERGER, Christa e HENN, Ronaldo (orgs. )Jornalismo e acontecimento: diante da morte. Florianópolis: Insular, 2012.

BIRD, Elizabeth; DARDENE, Robert W. Mito, registo e 'estórias': explorando as qualidades narrativas da notícia. In: TRAQUINA, Nelson (org.). Jornalismo: questões, teorias e 'estórias'. Lisboa: Veja, 1993

BRASIL. Ministério da Justiça. Levantamento nacional de informações penitenciárias - Infopen Junho 2014 . Brasília: [s.n.]. , 2014 ${ }^{\mathrm{a}}$

BRASIL. Ministério da Justiça. Levantamento nacional de informações penitenciárias - Infopen Mulheres- Junho 2014 . Brasília: [s.n.]. , 2014b

CONNEL, R. W.; MESSERSCHMIDT, James W. Hegemonic Masculinity: Rethinking the Concept. Gender \& Society v. 19, n. 6, p. 829-859, 2005.08912432. 
ENGEL, Magali. Psiquiatria e feminilidade In: PRIORE, Mary Del (org.).História das Mulheres no Brasil. São Paulo: Contexto, 1997, p. 322 - 361.

FARIA, Thaís Dumêt. A mulher e a criminologia: relações e paralelos entre a história da criminologia e a história da mulher no brasil. XIX Encontro Nacional do CONPEDI. Anais do... CONPEDI: Fortaleza, 2010.

FLAUZINA, Ana Luiza Pinheiro. Corpo negro caído no chão: o sistema penal e o projeto genocida do Estado brasileiro. Rio de Janeiro: Contraponto, 2008. .

FOUCAULT, Michel. Vigiar e Punir: história da violência nas prisões. 19a ed. Petrópolis: Vozes, 1999. .

JEWKES, Yvonne. Media \& Crime. London: Sage Publications, 2004

HALL, Stuart. et. al. (org;) A produção social das notícias: o mugging nos media. In: TRAQUINA, Nelson. Jornalismo: questões, teorias e "estórias". Lisboa: Veja, 1993, p. 224248. Lisboa, Veja.

LOMBROSO, Caesare; FERRERO, Willian(1903).The Female Offender. Disponível em: <http://brittlebooks.library.illinois.edu/brittlebooks_open/Books2009-

08/lombce0001femoff/lombce0001femoff.pdf f > Acesso em Outubro de 2013.

LOURO, Guacira Lopes. Gênero e Sexualidade: pedagogias contemporâneas. Pro-posições, Volume 19, nº 2 (56), Maio/Agosto, 2008, p. 17-22.

MATHEUS, Letícia. Narrativas do Medo: o jornalismo de sensações além do sensacionalismo. Rio de Janeiro: Mauad, 2011.

MENDES, Soraia da Rosa. Criminologia Feminista: novos paradigmas. São Paulo: Saraiva, 2014. .

MOTTA, Luiz Gonzaga. O trabalho simbólico da notícia. XII Reunião Anual do COMPOS Recife, Pernambuco, Junho, 2002a.

MOTTA, Luiz Gonzaga. O imaginário: em busca de uma síntese entre o ideológico e o simbólico na análise da dinâmica sócio-cultural latino-americana. Revista de Economía Política de las Tecnologías de la Información y Comunicación ww.eptic.com.br Vol.IV, n.3, Sep./Dic. $2002 b$.

MOTTA, Luiz Gonzaga. Análise crítica da narrativa. Brasília: Universidade de Brasília, 2013.

MORENO, Rachel. A beleza impossível. São Paulo: Agora, 2008.

ORLANDI, Eni. Análise de discurso: princípios e procedimentos. 3.ed. Campinas: Pontes, 2001.

PRIORE, Mary Del. Magia e Medicina na Colônia: o corpo feminino In: PRIORE, Mary Del (org).História das Mulheres no Brasil. São Paulo: Contexto, 1997, p. 79 - 114. 
POTTER, GARY. KAPPELER, VICTOR E. Constructing Crime: Perspective on Making News and Social Problems. Illinois: Waveland Press, 1998.

RUSCHE, Georg; KIRCHHEIMER, Otto. Pena y estructura social. Bogotá: Temis, 1984. .

SCOTT, Joan. Gênero: uma categoria útil de análise histórica. Revista Educação e realidade, Volume 20, nº 2, Julho/Dezembro. EDITORA: Porto Alegre, 1995, p. 71-99.

TRAQUINA, Nelson. Toerias do Jornalismo: a tribo jornalística - uma comunidade interpretativa transnacional. Florianópolis: Insular, 2005.

VEIGA DA SILVA, Márcia. Masculino, o gênero do Jornalismo: um estudo sobre os modos de produção das notícias. Dissertação de Mestrado. PPG em Comunicação e Informação. UFRGS, Porto Alegre, 2010.

WELCH, Michael; FENWICK, Melissa. ROBERTS, Meredith. State managers, intellectuals, and the media: a content analysis of ideology in experts' quotes in feature newspaper articles on crime - In POTTER, Gary. KAPPELER, Victor E. (org.) Constructing Crime: Perspective on Making News and Social Problems. Illinois: Waveland Press, 1998 p. 70-91.

WOLF, Mauro. Teorias da comunicação de massa. São Paulo: Martins Fontes, 2003. 